\title{
A defeat for primate research
}

T wo years ago, we discussed the protests against a planned center for primate neuroscience research at the University of Cambridge $^{1}$, concluding that the outcome of this battle would be an important test of whether the research community can respond effectively to new tactics being used by animal rights activists. Now the verdict is in, and the news is not good for scientists.

On January $27^{\text {th }}$, Pro-Vice-Chancellor Tony Minson announced that the university had decided to cancel its plans to build the new center. "This has not been an easy decision to reach," he said "but ultimately, we have a responsibility to our students and staff not to take financial risks of this magnitude." The university administration denied it was giving in to harassment, but admitted that the protests were a substantial contributor to the cost increases that were cited as the reason for the cancellation. Construction of the center was originally budgeted for $£ 24$ million (US\$43.4 million), with most of the money pledged by the Wellcome Trust. By January of this year, the estimate had risen to $£ 32$ million. The anticipated cost of long-term additional security in running the facility also contributed to the university's decision to cancel the project.

The Cambridge center was intended to be the largest primate research facility in the UK, housing several hundred marmosets and macaques, but it was soon targeted by an organization called Stop Primate Experiments At Cambridge (SPEAC). The first major snag came in February 2002, when the local council denied the university's application for planning permission, saying the center was likely to attract violent protests that would be a threat to public safety and increase police costs. Britain's Deputy Prime Minister, John Prescott, later overruled the council, saying the research was in the national interest. Two animal rights groups filed a lawsuit challenging this decision, noting that an independent planning inspector had found that the university could not establish a "national need" for the center. Less than a month later, the university announced the project's cancellation.

What they cannot win through public opinion or legal action, animal rights activists are increasingly gaining by putting pressure on people who do not have a stake in the fight, such as suppliers, customers and financial backers of biomedical companies and universities. "This is a much more sophisticated campaign. This is the next generation," says Frankie Trull, president of the Foundation for Biomedical Research, of the Cambridge protests. Their recent success has clearly bolstered the activists' faith in the new approach. A report from the Association of British Pharmaceutical Industries says 12 supplier companies announced they would stop doing work for pharmaceutical companies or animal breeders in January and February alone. In the same period, drug companies reported 36 incidents of damage to property, mainly personal property, and 15 public protests, many at employees' homes. Indirect pressure has been less common outside the UK so far, but if it is seen to be effective, it seems likely to spread to other countries in short order.
The tactics that were used against the Cambridge center were honed in the four-year-old campaign against Huntingdon Life Sciences, a contract research company for the pharmaceutical industry located nearby. Those protests have included sustained harassment, assault and an orchestrated campaign of targeting the company's suppliers and financial investors for protests. Last year the company's auditor Deloitte \& Touche resigned after activists provided employees' home addresses on the web and visited their homes. This spring the Chiron Corporation, an international pharmaceutical firm that is linked to Huntingdon, was granted an injunction against protests at its UK offices or the homes of its employees. Activist websites later publicized the home addresses and telephone numbers of two judges involved in the case-along with similar information for their mothers and one's mother-in-law.

As for the coalition that defeated the Cambridge center, it has a

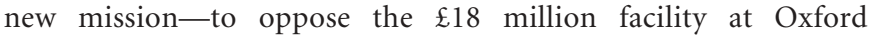
University, currently under construction, that is intended to bring all the university's laboratory animals into one building. The university says $98 \%$ of the animals housed there would be rodents, though the SPARC website focuses on primates used by two laboratories. (A substantial majority of the public in the UK-and the US - continues to support animal research, but support is weaker for primate research than for work on rodents.) In early April, one of Britain's largest suppliers of construction materials, Travis Perkins, announced that it would no longer deliver to the Oxford site. The company refused to give a reason for its decision, but a SPEAC spokesman said the company's policy change followed an appeal from the animal rights group.

One must expect that many companies will choose peace over principle when forced to take sides in such a battle. "A bank is not prepared for this kind of campaign. Its employees aren't prepared; its customers aren't prepared. They do have to worry about the bigger picture," notes Trull. In the UK, city and national governments concerned about the economic consequences of such protests are evaluating ways to discourage activists from pressuring the companies that finance businesses with which they disagree. Tougher regulations on protesters would be a welcome step forward, but more action is needed.

The scientific community needs to find a more effective way to counter these indirect tactics by animal rights groups, as universities cannot avoid constructing new buildings forever. Trull suggests, "The only way to turn this around in my opinion is to get the public to turn against the activists and become intolerant of them." Another possibility would be to take advantage of the collective economic clout of universities and other research organizations by refusing to deal with companies that give in to such pressure. Whatever the ultimate solution, it is clearly time for scientists to take these new tactics very seriously.

1. Activists threaten British neuroscience. Nat. Neurosci. 5, 285 (2002). 